\title{
T-B+ severe combined immunodeficiency
}

INSERM

\section{Source}

INSERM. (1999). Orphanet: an online rare disease and orphan drug data base. $\underline{T-B+}$ severe combined immunodeficiency. ORPHA:317416

$\mathrm{T}-\mathrm{B}+$ severe combined immunodeficiency (SCID; see this term) is a group of rare monogenic primary immunodeficiency disorders characterized by a lack of functional peripheral T lymphocytes with presence of B lymphocytes, resulting in early-onset severe respiratory viral, bacterial or fungal infections, diarrhea and failure to thrive. 